\title{
Course of migraine during pregnancy among migraine sufferers before pregnancy
}

\author{
Waldmiro Antônio Diégues Serva', Vilneide Maria Santos Braga Diégues Serva², \\ Maria de Fátima Costa Caminha3 ${ }^{3}$, José Natal Figueiroa ${ }^{4}$, \\ Emídio Cavalcanti Albuquerque5, Gabriel Braga Diégues Serva6, \\ Marcela Patrícia Macêdo Belo ${ }^{7}$, Malaquias Batista Filho ${ }^{8}$, Marcelo Moraes Valença ${ }^{9}$
}

\begin{abstract}
Objective: To describe the course of migraine without aura and migraine with aura during pregnancy and factors that could influence its course, among migraine sufferers before pregnancy. Method: A cross sectional study undertaken at the IMIP, Brazil. Out of 686 consecutively assisted women, at the first postnatal week, 266 were identified as migraine sufferers before pregnancy. Results: There was migraine remission in $35.4 \%$, $76.8 \%$ and $79.3 \%$ among migraine without aura sufferers and $20.7 \%, 58.6 \%$ and $65.5 \%$ among those with migraine with aura, respectively in the first, second and third trimesters. Statistically significant difference was found when the first trimester was compared with the second and third trimesters. The factors associated with the presence of migraine during pregnancy were: multiparity, menstrually related migraine without aura prior to pregnancy and illness during pregnancy. Conclusion: The study contributed to elucidate the course of migraine during pregnancy in migraine sufferers prior to pregnancy.
\end{abstract}

Key words: migraine without aura, migraine with aura, pregnancy.

\section{Comportamento da enxaqueca durante a gestação em mulheres portadoras de enxaqueca pré-gestacional}

\section{RESUMO}

Objetivo: Descrever o comportamento da enxaqueca com e sem aura durante a gestação e fatores que possam influenciar o seu curso, em mulheres com enxaqueca antes da gestação. Método: Estudo transversal realizado no IMIP, Brasil. De 686 mulheres consecutivamente assistidas na primeira semana pós-parto, 266 foram identificadas como portadoras de enxaqueca antes da gestação. Resultados: Houve desaparecimento das crises de enxaqueca, tanto na enxaqueca sem aura em 35,4\%,76,8\% e 79,3\%, como na enxaqueca com aura em $20,7 \%, 58,6 \%$ e $65,5 \%$, respectivamente no primeiro, segundo e terceiro trimestres de gestação, com diferença estatisticamente significante quando se comparou o primeiro, com o segundo e terceiro trimestres. Os fatores associados à presença de crises de enxaqueca foram: multiparidade, enxaqueca sem aura relacionada à menstruação antes de gestação e doença durante a gestação. Conclusão: $O$ estudo contribuiu para elucidar o comportamento da enxaqueca durante a gestação em mulheres com enxaqueca antes da gestação.

Correspondence

Waldmiro Antônio Diégues Serva

Rua Astronauta Neil

Armstrong 120/1302

52060-170 Recife PE - Brasil

E-mail:wserva@hotmail.com

\section{Conflicts of interest}

The authors report no conflict of interest

Received 29 December 2010 Received in final form 29 April 2011 Accepted 6 May 2011
Palavras-chave: enxaqueca sem aura, enxaqueca com aura, gravidez.

${ }^{1} \mathrm{PhD}$ in Neuroscience and Lecturer at the Department of Neuropsiquiatry of the Universidade Federal de Pernambuco (UFPE), Recife PE, Brazil; ${ }^{2} \mathrm{MsC}$ in Mother and Child Health at the University of London and Head of the Breast Milk Bank and Center of Incentive of Breastfeeding at the Instituto de Medicina Integral Professor Fernando Figueira (BLH/CIAMA/ IMIP), Recife PE, Brazil; ${ }^{3} \mathrm{PhD}$ in Nutrition, UFPE and Researcher at the Research Department of the Instituto de Medicina Integral Professor Fernando Figueira (IMIP), Recife PE, Brazil; ${ }^{4} \mathrm{MsC}$ in Statistics at Washington University and Researcher at the Research Department, IMIP; ${ }^{5}$ MsC in Public Health at Aggeu Magalhães/FIOCRUZ and Statistician, IMIP; ${ }^{6}$ Medical Student of the Faculdade Pernambucana de Saúde (FPS), Recife PE, Brazil; ${ }^{7}$ Nursing Student, FPS; ${ }^{8} \mathrm{PhD}$ in Public Health. Professor and Reasercher at the Research Department, IMIP; ${ }^{9} \mathrm{PhD}$ in Neuroendocrinology and Lecturer at the Department of Neuropsiquiatry, UFPE. 
Migraine is one of the most common neurological disorders among women, with a female/male proportion of 3-4:1 $1^{1}$. Its prevalence among women varies from $4 \%$ before puberty to $25 \%$ during the reproductive life, decreasing later in perimenopause and post-menopause ${ }^{1}$. One knows that migraine behavior during women's reproductive life is influenced by cyclical fluctuations in sex hormones ${ }^{2-4}$, with attacks that occur predominantly during the menstrual period ${ }^{4,5}$. Changes in migraine frequency can also occur during pregnancy, lactation ${ }^{6}$ and contraceptive use ${ }^{2}$.

The hypothalamic-pituitary-ovarian axes regulates hormonal fluctuations associated to the menstrual cycle ${ }^{7}$ and the abrupt decline in estrogen seems to play a key role in triggering menstrual migraine ${ }^{8}$. This also occurs during the week of hormonal suspension in women that use combined oral contraceptives ${ }^{9}$ and in the immediate postpartum period ${ }^{10}$, what could explain the increase in migraine attacks during these periods ${ }^{3}$.

During pregnancy, the frequency of migraine decreases in most women, with an increase in its remission from the first to the third trimester ${ }^{6}$. One of the explanations for these findings is the increased levels of estrogen in the first trimester and a tendency to stability during the second and third trimesters of pregnancy ${ }^{3}$.

The aim of the present study is to describe the course of with and without aura migraine during pregnancy, in a group of migraine sufferers before pregnancy, as well as associated factors that could influence its course.

\section{METHOD}

It is a retrospective study undertaken at the Breast Milk Bank (BMB) of the Instituto de Medicina Integral Professor Fernando Figueira (IMIP) in Recife PE, Brazil, for a period of six months.

A questionnaire was applied to all women assisted, around the eighth postpartum day (between the seventh and the tenth day), for the first postnatal visit at the Outpatient Clinic of the BMB/IMIP, that had given birth in the Maternity Unit of the Institution, after signing the Consent Form. So, there was no bias in the sample selection, given the fact that all women were consecutively enrolled in the study.

The data collection form included questions related to socioeconomic (maternal education, per capita income, maternal age, race/skin color, marital status, occupation), obstetric (number of pregnancies and diseases during pregnancy) and biological factors (migraine without aura - MO before pregnancy and migraine with aura - MA before pregnancy, related or not to tension type headache - TTH before pregnancy and family history of migraine).

$\mathrm{MO}$ and MA sufferers before pregnancy, classified according to the International Classification of Headache Disorders (ICHD-2004) $)^{11}$, were included in the sample. Postpartum women with neurological diseases that could characterize secondary headache and those that disagreed in taking part in the study would form the exclusion group.

Although the definition of pure menstrual migraine and menstrually related migraine refers only to $\mathrm{MO}^{11}$, we called menstrually related migraine, those that occurred only during the menstrual cycle as well as those that also occurred outside it, in both MO and MA cases. The two categories were grouped in view of the difficulties of a retrospective identification, due to the fact that the questionnaire was applied in the postpartum period.

Independent variables that constitute risk or protection factors, according to the literature ${ }^{6}$, for the presence of migraine attacks during pregnancy, were selected. Socioeconomic and demographic factors formed the first block of variables (maternal education, per capita income, maternal age, race/color of the skin). The second block included variables related to obstetric factors (number of pregnancies and diseases during pregnancy) and the third block included biological factors related to migraine and headache history in the family. The outcome was represented by the presence of migraine attacks in the first or second or third trimester of pregnancy.

The statistical significance of each variable was calculated using the Wald test for heterogeneity. The bivariate analysis allowed to identify the explanatory variables considering as screening criteria the associations with $\mathrm{p}<0.20$. Next, a multivariate analysis using Poisson multiple regression with robust standard error was performed, the adjusted prevalence ratios were estimated, their respective $95 \%$ confidence intervals and the statistical significance, adopting a $\mathrm{p} \leq 0.05$, using the same tests described before. To compare the trimesters with the occurrence of migraine attacks during pregnancy, the McNemar test was used and the p values obtained were adjusted by the Holm's method. Stata 9.2 SE was used to analyze the data.

The research project, under the number 1389, was approved by the Ethical Committee for Research in Human Beings of IMIP, in an Ordinary Meeting of April $16^{\text {th }}, 2009$.

\section{RESULTS}

Between June and November 2009, 686 women who had given birth at the Maternity Unit of IMIP were assisted in the Outpatient Clinic of the BMB/IMIP for the first postnatal visit. Of these, $266(38.8 \%)$ were identified as MO $(237,89.1 \%)$ and MA $(29,10.9 \%)$ sufferers before pregnancy. The association with TTH occurred in 59 (22.2\%) women. Of the 266 women, 131 (42.2\%) 
had menstrually related migraine before pregancy, most of them (87.8) were MO patients and only $12.2 \%$ were MA sufferers.

Most of the women had finished high school (75.5\%) and were poor, with a per capita income less than half the national minimum wage (70.7\%). The mean age was 27 years, they reported themselves as black/colored
(70.7\%), were married or had a consensual union (85.8\%), did not work (60.2\%) and were primigravids (59.4\%). The majority of them had vaginal deliveries (66.2\%). Eightythree women $(31.2 \%)$ had diseases during pregnancy. Of these, 60 (22.6\%) had hypertension, 21 (7.9\%) diabetes and 17 (6.4\%) urinary tract infection. High blood pressure was the only disease that showed a statistically sig-

Table 1. Presence of migraine during pregnancy, among 266 migraine sufferers before pregnancy.

\begin{tabular}{lccc}
\hline Type of migraine before pregnancy & $\begin{array}{c}1^{\text {st }} \text { trimester } \\
\%(n / \text { total) }\end{array}$ & $\begin{array}{c}2^{\text {nd }} \text { trimester } \\
\%(n / \text { total) }\end{array}$ & $\begin{array}{c}3^{\text {rd }} \text { trimester } \\
\%(n / t o t a l)\end{array}$ \\
\hline Migraine without aura ${ }^{1,2}$ & $64.6(153 / 237)$ & $23.2(55 / 237)$ & $20.7(49 / 237)$ \\
Migraine with aura ${ }^{3,4}$ & $79.3(23 / 29)$ & $41.4(12 / 29)$ & $34.5(10 / 29)$ \\
Migraine with and without aura $^{6,7}$ & $66.2(176 / 266)$ & $25.2(67 / 266)$ & $22.2(59 / 266)$ \\
\hline
\end{tabular}

${ }^{1-7}$ McNemar test, adjusted $p$ value by Holm's method; ${ }^{1,6} p<0.001$, comparing the first with the second and with third trimesters; ${ }^{2} p=0.210$, comparing the second with the third trimester; ${ }^{3} p=0.015$, comparing the first with the second trimester; ${ }^{4} p<0.001$, comparing the first with the third trimesters; ${ }^{5} p=0.500$, comparing the second and third trimesters; ${ }^{7} \mathrm{p}=0.096$, comparing the second with the third trimester.

Table 2. Crude and adjusted prevalence ratios (PR), with 95\% confidence interval (95\% Cl), according to independent variables for migraine attacks in the $1^{\text {st }}$ trimester of pregnancy among 266 with and without aura migraine sufferers before pregnancy.

\begin{tabular}{|c|c|c|c|c|c|c|c|c|}
\hline Indenpendent variables & & $\begin{array}{c}\text { Migraine attacks } \\
1^{\text {st }} \text { trimester } \\
\% \text { (n/total) }\end{array}$ & $\begin{array}{c}\text { Crude } \\
\text { PR }\end{array}$ & $\begin{array}{c}95 \% \\
\mathrm{Cl}\end{array}$ & $\mathrm{P}^{\mathrm{a}}$ & $\begin{array}{l}\text { Adjusted } \\
\text { PR }\end{array}$ & $\begin{array}{c}95 \% \\
\mathrm{Cl}\end{array}$ & $\mathrm{Pa}^{\mathrm{a}}$ \\
\hline \multicolumn{9}{|l|}{ Socioeconomic and demographic factors } \\
\hline \multirow[t]{2}{*}{ Years of schooling } & $1^{\text {st }}$ to $8^{\text {th }}$ & $72.3(47 / 65)$ & 1.13 & $0.94-1.35$ & 0.201 & - & - & - \\
\hline & 9 ou more & $64.2(129 / 201)$ & 1 & & & & & \\
\hline \multirow[t]{2}{*}{ Per capita income (minimum wage) } & $<0.5$ & $68.1(128 / 188)$ & 1.11 & $0.90-1.35$ & 0.325 & - & - & - \\
\hline & $>0.5$ & $61.5(48 / 78)$ & 1 & & & & & \\
\hline \multirow[t]{2}{*}{ Maternal age } & $<27$ years old & $66.7(90 / 135)$ & 1.02 & $0.85-1.21$ & 0.861 & - & - & - \\
\hline & $\geq 27$ years old & $65.6(86 / 131)$ & 1 & & & & & \\
\hline \multirow[t]{2}{*}{ Race/skin color } & White & $60.3(47 / 78)$ & 0.88 & $0.72-1.08$ & 0.214 & - & - & - \\
\hline & Black/colored & $68.6(129 / 188)$ & 1 & & & & & \\
\hline \multicolumn{9}{|l|}{ Obstetric factors } \\
\hline \multirow[t]{2}{*}{ Number of pregnancies } & 1 & $59.5(94 / 158)$ & 0.78 & $0.66-0.93$ & 0.004 & 0.79 & $0.67-0.94$ & 0.006 \\
\hline & $>1$ & $75.9(82 / 108)$ & 1 & & & 1 & & \\
\hline \multirow[t]{2}{*}{ Disease during pregnancy } & Yes & $75.9(63 / 83)$ & 1.23 & $1.04-1.45$ & 0.015 & 1.19 & $1.01-1.40$ & 0.039 \\
\hline & No & $61.7(113 / 183)$ & 1 & & & 1 & & \\
\hline \multicolumn{9}{|l|}{ Biological factors } \\
\hline \multirow{2}{*}{$\begin{array}{l}\text { Menstrually related } \\
\text { Migraine without aura before pregnancy }\end{array}$} & Yes & $73.9(85 / 115)$ & 1.23 & $1.04-1.45$ & 0.018 & 1.21 & $1.02-1.42$ & 0.025 \\
\hline & No & $60.3(91 / 151)$ & 1 & & & 1 & & \\
\hline \multirow{2}{*}{$\begin{array}{l}\text { Menstrually related } \\
\text { Migraine with aura before pregnancy }\end{array}$} & Yes & $75.0(12 / 16)$ & 1.14 & $0.85-1.54$ & 0.377 & - & - & - \\
\hline & No & $65.6(164 / 250)$ & 1 & & & & & \\
\hline \multirow{2}{*}{$\begin{array}{l}\text { Tension type headache } \\
\text { before pregnancy }\end{array}$} & Yes & $69.2(18 / 26)$ & 0.87 & $0.69-1.10$ & 0.242 & - & - & - \\
\hline & No & $65.8(158 / 240)$ & 1 & & & & & \\
\hline \multirow[t]{2}{*}{ Family history of headache } & Yes & $66.9(160 / 239)$ & 1.13 & $0.82-1.56$ & & - & - & - \\
\hline & No & $59.3(16 / 27)$ & 1 & 0.463 & & & & \\
\hline
\end{tabular}

${ }^{a}$ Wald test for heterogeneity; variables highlighted in black were included in the multivariate analysis. 
nificant association (chi-square) with migraine attacks in the second $(\mathrm{p}=0.004)$ and third $(\mathrm{p}<0.001)$ trimester of pregnancy. As diagnoses were retrospective one was unable to specify which type of hypertension or diabetes women had during pregnancy.

None of the women experiencing remission during the first and second trimester of pregnancy showed migraine attacks in the third trimester. Fifty nine women continued to have migraine attacks during all the gestation period.

Table 1 shows a statistically significant difference between the frequency of $\mathrm{MO}$ and MA in the first trimester, compared with the second and third trimester of pregnancy among $\mathrm{MO}$ and MA sufferers before pregnancy. There was no statistical difference in migraine frequencies between the second and third trimester of preg- nancy in relation to $\mathrm{MO}$ and MA sufferers, respectively, $\mathrm{p}=0.210$ and $\mathrm{p}=0.500$.

Among the 59 women that had TTH associated with MO or MA before pregnancy, there was also a statistically significant difference when the presence of TTH in the first trimester 35 (59.3\%) was compared with the second 15 (25.4\%) and the third 13 (22.0\%) trimester of pregnancy using the McNemar test, with adjusted $\mathrm{p}$ value by Holm's method ( $\mathrm{p}<0.001)$. No statistical difference was found when the second trimester was compared with the third trimester of pregnancy $(p=0.625)$.

Tables 2, 3 and 4 show, respectively, the results of the bivariate and multivariate analysis of the associated factors to migraine attacks in the first, second and third trimesters of pregnancy among women with $\mathrm{MO}$ and MA before pregnancy.

Table 3. Crude and adjusted prevalence ratios (PR), with 95\% confidence interval ( $95 \% \mathrm{Cl})$, according to independent variables for migraine attacks in the second trimester of pregnancy among 266 with and without aura migraine sufferers before pregnancy.

\begin{tabular}{|c|c|c|c|c|c|c|c|c|}
\hline Indenpendent variables & & $\begin{array}{c}\text { Migraine attacks } \\
2^{\text {st }} \text { trimester } \\
\% \text { (n/total) }\end{array}$ & $\begin{array}{c}\text { Crude } \\
\text { PR }\end{array}$ & $\begin{array}{c}95 \% \\
\mathrm{Cl}\end{array}$ & $\mathrm{Pa}^{\mathrm{a}}$ & $\begin{array}{l}\text { Adjusted } \\
\text { PR }\end{array}$ & $95 \% \mathrm{Cl}$ & $\mathrm{Pa}^{\mathrm{a}}$ \\
\hline \multicolumn{9}{|l|}{ Socioeconomic and demographic factors } \\
\hline \multirow[t]{2}{*}{ Years of schooling } & $1^{\text {st }}$ to $8^{\text {th }}$ & $21.5(14 / 65)$ & 0.82 & $0.49-1.37$ & 0.445 & - & - & - \\
\hline & 9 ou more & $26.4(53 / 201)$ & 1 & & & & & \\
\hline \multirow[t]{2}{*}{ Per capita income (minimum wage) } & $<0.5$ & $25.5(48 / 188)$ & 1.05 & $0.66-1.66$ & 0.842 & - & - & - \\
\hline & $>0.5$ & $24.4(19 / 78)$ & 1 & & & & & \\
\hline \multirow[t]{2}{*}{ Maternal age } & $<27$ years old & $25.9(35 / 135)$ & 1.06 & $0.70-1.61$ & 0.779 & - & - & - \\
\hline & $\geq 27$ years old & $24.4(32 / 131)$ & 1 & & & & & \\
\hline \multirow[t]{2}{*}{ Race/skin color } & White & $30.8(24 / 78)$ & 1.35 & $0.88-2.06$ & 0.171 & 1.37 & $0.89-2.09$ & 0.153 \\
\hline & Black/colored & $22.9(43 / 188)$ & 1 & & & 1 & & \\
\hline \multicolumn{9}{|l|}{ Obstetric factors } \\
\hline \multirow[t]{2}{*}{ Number of pregnancies } & 1 & $19.6(31 / 158)$ & 0.59 & $0.39-0.89$ & 0.012 & 0.60 & $0.40-0.91$ & 0.015 \\
\hline & $>1$ & $33.3(36 / 108)$ & 1 & & & 1 & & \\
\hline \multirow[t]{2}{*}{ Disease during pregnancy } & Yes & $32.5(27 / 83)$ & 1.49 & $0.98-2.25$ & 0.060 & 1.44 & $0.95-2.17$ & 0.086 \\
\hline & No & $21.9(40 / 183)$ & 1 & & & 1 & & \\
\hline \multicolumn{9}{|l|}{ Biological factors } \\
\hline \multirow{2}{*}{$\begin{array}{l}\text { Menstrually related } \\
\text { Migraine without aura before pregnancy }\end{array}$} & Yes & $22.6(26 / 115)$ & 0.83 & $0.54-1.28$ & 0.402 & - & - & - \\
\hline & No & $27.2(41 / 151)$ & 1 & & & & & \\
\hline \multirow{2}{*}{$\begin{array}{l}\text { Menstrually related } \\
\text { Migraine with aura before pregnancy }\end{array}$} & Yes & $43.8(7 / 16)$ & 1.82 & $1.00-3.32$ & 0.049 & 1.56 & $0.86-2.85$ & 0.147 \\
\hline & No & $24.0(60 / 250)$ & 1 & & & 1 & & \\
\hline \multirow{2}{*}{$\begin{array}{l}\text { Tension type headache } \\
\text { before pregnancy }\end{array}$} & Yes & $34.6(9 / 26)$ & 1.01 & $0.62-1.66$ & 0.962 & - & - & - \\
\hline & No & $24.2(58 / 240)$ & 1 & & & & & \\
\hline \multirow[t]{2}{*}{ Family history of headache } & Yes & $25.5(61 / 239)$ & 1.15 & $0.55-2.41$ & 0.714 & - & - & - \\
\hline & No & $22.2(6 / 27)$ & 1 & & & & & \\
\hline
\end{tabular}

${ }^{a}$ Wald test for heterogeneity; variables highlighted in black were included in the multivariate analysis. 
Multiparity, the presence of disease during pregnancy and menstrually related $\mathrm{MO}$ before pregnancy had statistically significant association with the presence of migraine attacks in the first trimester of pregnancy, both after bivariate and multivariate analysis (Table 2).

Although in the bivariate analysis, the number of pregnancies and menstrually related MA before pregnancy showed a significant association, after Poisson's multiple regression analysis only the number of pregnancies showed a statistically significant association in the second trimester of pregnancy (Table 3).

After multivariate analysis, Table 4 shows that only the presence of disease during pregnancy had a statistically significant association with the presence of migraine attacks in the third trimester of pregnancy, although per capita income, number of pregnancies, dis- ease during pregnancy and menstrually related MA before pregnancy had also entered the multivariate analysis.

\section{DISCUSSION}

Although the prevalence of migraine during the woman's reproductive life is around $25.0 \%{ }^{1}$, with $60.0 \%$ of the cases being menstually related ${ }^{4}$ and of those $83.0 \%$ and $3.0 \%$, respectively of MO and MA cases ${ }^{12}$, the present study found $38.8 \%$ of migraines sufferers before pregnancy, and $42.2 \%$ of those related to menstruation. Of the menstrually related migraine sufferers, 115 (87.8\%) were MO cases, what corresponded to the findings of Miziara et al. ${ }^{12}$. However, with regards to MA the present study showed 16 (12.2\%) women suffering from menstrually related MA before pregnancy. The differences found may be explained because, first of all it is

Table 4. Crude and adjusted prevalence ratios (PR), with 95\% confidence interval (95\% Cl), according to independent variables for migraine attacks in the third trimester of pregnancy among 266 with and without aura migraine sufferers before pregnancy.

\begin{tabular}{|c|c|c|c|c|c|c|c|c|}
\hline Indenpendent variables & & $\begin{array}{c}\text { Migraine } \\
\text { recurrence } \\
3^{\text {rd }} \text { postpartum } \\
\text { week \% (n/total) }\end{array}$ & $\begin{array}{c}\text { Crude } \\
\text { PR }\end{array}$ & $95 \% \mathrm{Cl}$ & $\mathrm{P}^{\mathrm{a}}$ & $\begin{array}{l}\text { Adjusted } \\
\text { PR }\end{array}$ & $95 \% \mathrm{Cl}$ & $\mathrm{p}^{\mathrm{a}}$ \\
\hline \multicolumn{9}{|l|}{ Socioeconomic and demographic factors } \\
\hline \multirow[t]{2}{*}{ Years of schooling } & $1^{\text {st }}$ to $8^{\text {th }}$ & $21.5(14 / 65)$ & 0.96 & $0.57-1.64$ & 0.887 & - & - & - \\
\hline & 9 ou more & $22.4(45 / 201)$ & 1 & & & & & \\
\hline \multirow[t]{2}{*}{ Per capita income (minimum wage) } & $<0.5$ & $24.5(46 / 188)$ & 1.47 & $0.84-2.56$ & 0.177 & 1.40 & $0.82-2.39$ & 0.217 \\
\hline & $>0.5$ & $16.7(13 / 78)$ & 1 & & & 1 & & \\
\hline \multirow[t]{2}{*}{ Maternal age } & $<27$ years old & $23.7(32 / 135)$ & 1.15 & $0.73-1.81$ & 0.545 & - & - & - \\
\hline & $\geq 27$ years old & $20.6(27 / 131)$ & 1 & & & & & \\
\hline \multirow[t]{2}{*}{ Race/skin color } & White & $23.1(18 / 78)$ & 1.56 & $0.65-1.72$ & 0.820 & - & - & - \\
\hline & Black/colored & $21.8(41 / 188)$ & 1 & & & & & \\
\hline \multicolumn{9}{|l|}{ Obstetric factors } \\
\hline \multirow[t]{2}{*}{ Number of pregnancies } & 1 & $17.7(28 / 158)$ & 0.62 & $0.39-0.87$ & 0.035 & 0.68 & $0.43-1.05$ & 0.082 \\
\hline & $>1$ & $28.7(31 / 108)$ & 1 & & & 1 & & \\
\hline \multirow[t]{2}{*}{ Disease during pregnancy } & & $34.9(29 / 83)$ & 2.13 & $1.37-3.31$ & 0.001 & 2.05 & $1.32-3.17$ & 0.001 \\
\hline & & $16.4(30 / 183)$ & 1 & & & 1 & & \\
\hline \multicolumn{9}{|l|}{ Biological factors } \\
\hline \multirow{2}{*}{$\begin{array}{l}\text { Menstrually related } \\
\text { Migraine without aura before pregnancy }\end{array}$} & Yes & $20.0(23 / 115)$ & 0.84 & $0.53-1.33$ & 0.458 & - & - & - \\
\hline & No & $23.8(36 / 151)$ & 1 & & & & & \\
\hline \multirow{2}{*}{$\begin{array}{l}\text { Menstrually related } \\
\text { Migraine with aura before pregnancy }\end{array}$} & Yes & $37.5(6 / 16)$ & 1.77 & $0.90-3.49$ & 0.099 & 1.62 & 0.85-3.09 & 0.142 \\
\hline & No & $21.2(53 / 250)$ & 1 & & & 1 & & \\
\hline \multirow{2}{*}{$\begin{array}{l}\text { Tension type headache } \\
\text { before pregnancy }\end{array}$} & Yes & $30.8(8 / 26)$ & 0.99 & $0.58-1.71$ & 0.976 & - & - & - \\
\hline & No & $21.3(51 / 240)$ & 1 & & & & & \\
\hline \multirow[t]{2}{*}{ Family history of headache } & Yes & $22.2(53 / 239)$ & 1.00 & $0.47-2.10$ & 0.996 & - & - & - \\
\hline & No & $22.2(6 / 27)$ & 1 & & & & & \\
\hline
\end{tabular}

aWald test for heterogeneity; variables highlighted in black were included in the multivariate analysis. 
a retrospective study and also because it is a hospital centered sample, although consecutive, which included all subjects attending the first postpartum visit. A study in which the questionnaires were applied 3 days after birth, inquiring about the prevalence of migraine (MO and MA) before pregnancy, also showed higher prevalence rates, of $29.3 \%^{13}$.

During pregnancy there is a decrease or even complete cessation of migraine attacks in both, MO and MA sufferers before pregnancy $y^{6,13-15}$. However, in MA cases the improvement and/or remission is lower during pregnancy $y^{14,15}$, what was also demonstrated in the present study. Complete remission of $\mathrm{MO}$ attacks was found in $10.6 \%, 53.2 \%$ and $78.7 \%$, respectively, in the first, second and third trimesters of pregnancy, with statistically significant differences between the first and second trimester and also when the second trimester was compared with the third trimester of pregnancy ${ }^{6}$. The present study corroborates with the literature findings ${ }^{6,13-15}$, with complete remission among the MO cases in $35.4 \%, 76.8 \%$ and $79.3 \%$ and among those with MA in $20.7 \%, 58.6 \%$ e $65.5 \%$, respectively, in the first, second and third trimesters of pregnancy, with a statistically significance difference when one compared the first with the second and third trimesters of pregnancy. This difference was not confirmed between the second and third trimesters (Table 1), what was also not found in Maggioni et al. ${ }^{13}$.

The course of migraine is associated with estrogen levels, with the frequency of migraine attacks tending to decline during periods of its increase or stability ${ }^{2,3,16}$. These high estrogen levels, without fluctuations, affect migraine prevalence in the majority of the women, even in those with no history of pure menstrual migraine or menstrually related migraine $e^{6}$. It is known that the corpus luteum maintains the secretion of estrogen and progesterone up to the $10^{\text {th }}-12^{\text {th }}$ gestational week. Later, it is the placenta that assumes these secretions that continue to increase throughout pregnancy, although they tend to stabilize between the second and third trimesters of pregnancy $y^{6,17}$. Perhaps this is one possible explanation for the results found in the present study.

The increase in beta-endorphin levels during pregnancy, which have an antinociceptive effect, is also attributed as a possible reason for the changing in the course of migraine during this period ${ }^{18}$. It is also known that estrogen receptor in trigeminal ganglion neurons appear to regulate the expression of galanin and neuropeptide $\mathrm{Y}$, that are involved in the nociception, in the murine estrogen $c y c l{ }^{16}$. If these findings are confirmed in humans, this may be another explanation for the differences in migraine frequency during women's reproductive live.

In bivariate analysis, multiparity had a statistical significant association with a higher prevalence of migraine attacks during the three trimesters of pregnancy, and this association remained significant in the first and second trimesters, after multivariate analysis. In the literature search, there was a tendency for migraine attacks to increase during the third trimester of pregnancy in multiparous women ${ }^{19}$ and to have a higher prevalence throughout pregnancy, when compared with primiparous ${ }^{19,20}$. However, there are authors who did not find any significant differences in relation to parity and migraine attacks during pregnancy ${ }^{6}$. Multiparous have significantly more symptoms than primiparous women, including headaches ${ }^{21}$. Previous experiences of migraine attacks during pregnancy may generate an expectation of migraine attacks in future pregnancies ${ }^{22}$. This finding was demonstrated by a study that showed a decrease in somatic symptoms among primiparous women, whereas the same symptoms did not decrease or even increased in multiparous ${ }^{22}$.

The bivariate analysis allowed to identify the explanatory variables considering as screening criteria the associations with $\mathrm{p}<0.20$. Each of the three diseases reported by the women interviewed (hypertension, diabetes and urinary tract infection), would enter the multivariate analysis, with exception to diabetes in the first and second trimesters of pregnancy. But high blood pressure was the only disease that showed a significant association, in the second $(\mathrm{p}=0.004)$ and in the third $(\mathrm{p}<0.001)$ trimester of pregnancy in the bivariate analysis. However, it was not possible to enter these three diseases in the multivariate analysis because the independent variable, disease during pregnancy, contained them. In the bivariate analysis, to have disease during pregnancy in the first, second and third trimester of pregnancy showed a statistically significant association with migraine attacks during the gestational period. After multivariate analysis, this association was maintained in the first and third trimesters.

It is easy to understand how physical problems arising during pregnancy can cause anxiety and change the benefits that pregnancy brings to the course of migraine . $^{6}$ Another possible explanation for this association, especially in the third trimester, would be the fact that in both, migraine and preeclampsia cases, there are altered vasoreactivity and abnormal platelet behaviour ${ }^{23,24}$, with a higher prevalence of headaches among women with preeclampsia, and in particular, of migraine ${ }^{24,25}$. However, as the diagnosis were retrospective in the present study, one could not specify which type of hypertension the women had, if preeclampsia or hypertension prior to pregnancy.

In the bivariate analysis, be a menstrually related $\mathrm{MO}$ or MA sufferer before pregnancy, respectively in the first and second trimester of pregnancy, had a statistically significant association with migraine attacks during pregnancy. After Poisson's multiple regression analysis only 
menstrually related MO before pregnancy maintained the significant association. This fact is probably due to the definition used for menstrually related migraine, which included pure menstrual migraine and that related to menstruation, for both $\mathrm{MO}$ and MA cases.

The present study had the limitation of a retrospective recruitment, however it corroborates and also adds to the debate of a number of aspects of the course of migraine during pregnancy.

We conclude by reiterating that estrogen should be just one of the many factors that act as a trigger to migraine in susceptible women ${ }^{3}$. This has implications not only in the physiopathology of migraine, but also in its treatment, especially during pregnancy. So, new studies are necessary to contribute even further for the elucidation, not only of the course of migraine during pregnancy, but its many associated factors to the presence of migraine episodes during the gestational period, in migraine sufferers before pregnancy.

\section{REFERENCES}

1. Lipton RB, Bigal ME, Diamond M, et al. Migraine prevalence, disease burden, and the need for preventive therapy. Neurology 2007;68:343-349.

2. Brandes JL. The influence of estrogen on migraine: a systematic review. JAMA 2006;295:1824-1830.

3. Zacur HA. Hormonal changes throughout life in women. Headache 2006;46 (Suppl):S50-S55.

4. Granella F, Sances G, Zanferrari C, Costa A, Martignoni E, Manzoni GC. Migraine without aura and reproductive life events: a clinical epidemiological study in 1300 women. Headache 1993;33:385-389.

5. Silberstein SD. Sex hormones and headache. Rev Neurol 2000;156(Suppl 4): S30-S41.

6. Sances G, Granella F, Nappi RE, et al. Course of migraine during pregnancy and postpartum: a prospective study. Cephalalgia 2003;23:197-205.

7. Silberstein S. Physiology of the menstrual cycle. Cephalalgia 2000;20: 148-154.
8. Somerville BW. The role of estradiol withdrawal in the etiology of menstrual migraine. Neurology 1972;22:355-365.

9. Silberstein S, Merriam G. Sex hormones and headache. Neurology 1999;53 (Suppl):S3-S13.

10. Tulchinsky D, Korenman SG. The plasma estradiol as an index of fetoplacental function. J Clin Invest 1971;50:1490-1497.

11. Olesen J. The international classification of headache disorders, $2^{\text {nd }}$ ed. Cephalalgia 2004;24:1-151.

12. Miziara L, Bigal ME, Bordini CA, Speciali JG. Cefaleia menstrual. Estudo semiológico de 100 casos. Arq Neuropsiquiatr 2003;61:596-600.

13. Maggioni F, Alessi C, Maggino T, Zanchin G. Headache during pregnancy. Cephalalgia 1997;17:765-769.

14. Granella F, Sances G, Pucci E, Nappi RE, Ghiotto N, Nappi G. Migraine with aura and reproductive life events: a case control study. Cephalalgia 2000; 20:701-707.

15. Melhado EM, Maciel JA Jr, Guerreiro CA. Headache during gestation: evaluation of 1101 women. Can J Neurol Sci 2007;34:187-192.

16. Martin VT, Behbehani M. Ovarian hormones and migraine headache: understanding mechanisms and pathogenesis - part 2. Headache 2006;46: 365-386.

17. Tulchinsky D, Hobel CJ, Yeager E, Marshall JR. Plasma estrone, estradiol, estriol, progesterone and 17-hydroxyprogesterone in human pregnancy. I. Normal pregnancy. Am J Obstet Gynecol 1972;112:1095-1100.

18. Genazzani AR, Facchinetti F, Parrini D. $\beta$-Lipotropin and $\beta$-endorphin plasma levels during pregnancy. Clin Endocrinol 1981;14:409-418.

19. Scharff $L$, Marcus DA, Turk DC. Headache during pregnancy and in the postpartum: a prospective study. Headache 1997;37:203-210.

20. Aegidius K, Zwart JA, Hagen K, Stovner L. The effect of pregnancy and parity on headache prevalence: the Head-HUNT Study. Headache 2009;49: 851-859.

21. Oga M, Shono H, Kohara M, Ito $Y$, Tanaka T, Sugimori H. Chronological changes in subjective symptoms during pregnancy in nulliparous and multiparous women. Acta Obstet Gynecol Scand 1995;74:784-787.

22. Lubin B, Gardner SH, Roth A. Mood and somatic symptoms during pregnancy. Psychosom Med 1975;37:136-146.

23. Adeney KL, Williams MA. Migraine headaches and preeclampsia: an epidemiologic review. Headache 2006;46:794-803.

24. Facchinetti F, Allais G, D'Amico R, Benedetto C, Volpe A. The relationship between headache and preeclampsia: a case-control study. Eur J Obstet Gynecol Reprod Biol 2004;121:143-148.

25. Adeney KL, Williams MA, Miller RS, Frederick IO, Sorensen TK, Luthy DA. Risk of preeclampsia in relation to maternal history of migraine headaches. J Matern Fetal Neonatal Med 2005;18:167-172. 